\title{
The prostate transglutaminase, TGase-4, coordinates with the HGFL/MSP-RON system in stimulating the migration of prostate cancer cells
}

\author{
WEN G. JIANG ${ }^{1}$, LIN YE ${ }^{1}$, RICHARD J. ABLIN ${ }^{2}$, HOWARD G. KYNASTON ${ }^{1}$ and MALCOLM D. MASON ${ }^{1}$ \\ ${ }^{1}$ Metastasis and Angiogenesis Research Group, Cardiff University School of Medicine, Cardiff, UK; \\ ${ }^{2}$ Departments of Immunobiology and Pathology, Health Sciences Centre, University of Arizona \\ College of Medicine and the Arizona Cancer Centre, Tucson, AZ 85724-5049, USA
}

Received March 29, 2010; Accepted May 19, 2010

DOI: 10.3892/ijo_00000689

\begin{abstract}
The prostate transglutaminase, TGase-4, is a member of the transglutaminase family and is uniquely expressed in the prostate gland. The function of the protein is largely unknown, although an influence on cell motility and adhesion has been indicated. The present study investigated the impact of the differential expression of TGase-4 in human prostate cancer cells on RON, the hepatocyte growth factorlike/macrophage-stimulating protein (HGF-L/MSP) receptor, mediated cellular functions. Using human prostate cancer cell lines and prostate tissues, we demonstrated that human TGase-4 had a high degree of co-localisation with RON, primarily at the cell periphery and cell-cell adhesion region. High levels of TGase- 4 expression in CAHPV 10 cells and in PC3 cells engineered to over-express TGase-4 were associated with significantly increased cell motility in response to HGF-L, a clear contrast to wild-type and control cells. Neutralising antibody to RON and rhHGFL/MSP had no further bearing on the increased motility in TGase- 4 over-expressing cells, although they had profound effect on the control cells. Akt pathway inhibitor significantly diminished the effect induced by HGF-L in the cells. Finally, over-expression of TGase- 4 in prostate cancer cells resulted in autophosphorylation of RON. It is concluded that TGase-4 expression is intrinsically linked to the activation of RON in prostate cancer cells and that this autoactivation of RON contributes to the increased cell motility in TGase-4 expressing cells.
\end{abstract}

Correspondence to: Professor Wen G. Jiang, Metastasis and Angiogenesis Research Group, Cardiff University School of Medicine, Heath Park, Cardiff CF14 4XN, UK

E-mail: jiangw@cf.ac.uk

Key words: transglutaminase, transglutaminase-4, RON, hepatocyte growth factor-like, macrophage-stimulating protein, Akt pathway, cell motility, electric cell sensing, prostate cancer

\section{Introduction}

Transglutaminases [EC 2.3.2.13 (TGases)] are a family of proteins that catalyse the post-translational modification of proteins by the formation of $\varepsilon$-( $\gamma$-glutamyl) lysine isopeptide bonds. One of the unique TGases is the prostate transglutaminase (also known as TGase-4 or TGaseP). TGase-4 is largely confined to the prostate gland (1-3). TGases were implicated as contributory to the early suggested concept and role of the tumour microenvironment and tumorigenesis (4-7), regulate the adhesion to matrix and migration over matrix $(8,9)$. These controversial in vitro reports are reflected by clinical observations that TGase- 2 has been shown to be either favorably or inversely correlated with patients outcome (10).

There is little knowledge on the role of TGase-4 in cancer. Restricted to luminal epithelial cells (with no presence in basal epithelial cells or stromal cells), TGase-4 protein was observed in high-grade prostate intraepithelial neoplasia. TGase-4 was seen at a lower level in prostate cancer compared with normal tissues. Metastatic prostate tumours also showed lost of expression (11). The expression pattern of TGase-4 has not been found thus far for any other prostate-specific marker (12). Discovered from a human prostate cDNA library (2), the 679 AA transglutaminase was found to share homology with human endothelial cell TGase (88\%) and rat prostate TGase $(51 \%)$. In a recent study (13), we found the expression pattern of TGase-4 in cells from different tissue origin is broader than we initially anticipated. Colon cancer, lung cancer and prostate cancer cell lines have varying degrees of expression of the enzyme. This is an interesting observation, as previous studies have used normal human tissue cDNAs $(1,12,14)$. This indicates that the expression of TGase-4 may vary between the normal cells and the more genetic instable cancer cell counterpart. The function of the prostate TGase is far from clear. The rat homologue, rat prostate TGase (or DP1) has been suggested to be involved to some degree in sperm cell motility and immunogenicity $(15,16)$ and immunoregulation $(4,5)$. Our recent study (13) demonstrated that loss of TGase-4 from CAHPV10 cells resulted in the cells being less invasive with or without stimulation by hepatocyte growth factor. Furthermore, 
TGase- 4 has also been shown to influence the interaction between prostate cancer cells and endothelial cells (17). Together with the report that TGase can be up-regulated by androgen in PC346C, but not in LNCaP cells (despite both being androgen responsive cell lines) (1), this suggests that the enzyme may play a role in the control of invasiveness.

RON belongs to a small receptor-type protein tyrosine kinase family and is the receptor for the HGF-like protein (HGF-L, also known as MSP). RON is comprised of two subunits, joined by disulfide bonds with the $\beta$ subunit being the main functional unit of the receptor. Upon stimulation by HGF-L, two main clusters of tyrosine sites on the intracellular domain are activated/phosphorylated, Y1238/Y1239 site - the main catalytic site and Y1353/Y1360 - the main docking site of the RON. Downstream of RON activation are a few signalling pathways which ultimately lead to the specific cellular events, for example, Src/MAPK pathway for the mitogenic effect, PI3-K/Akt pathway for the growth/survival and motility effect elicited by HGF-L/MSP $(18,19)$. In cancer, RON is overexpressed in breast cancer, colorectal cancer, lung cancer and kidney cancer (20-22). Furthermore, HGF-L has been shown to have an increased expression in breast, lung and pancreatic cancers (21-24). So far, only limited information is available on RON and HGF-L expression in prostate cancer, in that the staining of RON total protein in tumour was not different from that in normal tissues.

In an attempt to decipher the molecular and cellular mechanisms underlying the action of TGase-4, we conducted a series of protein interaction by way of immunoprecipitation using proteins from human prostate tissues. One of the interacting proteins with TGase- 4 was RON. The present study examined how RON and TGase-4 interplayed in the regulation of cellular functions of prostate cancer cells.

\section{Materials and methods}

Materials and cell lines. Human prostate cancer cells, PC-3 and CAHPV10 were from American Type Cell Collection, Manassas, VI, USA. Fresh frozen prostate tissues were collected from University Hospital of Wales under the approval of local ethics committee and obtained immediately after surgery and stored at $-80^{\circ} \mathrm{C}$ until use.

Rh-HGF-L/MSP and anti-HGF-L receptor/RON (neutralising and non-neutralising were from R\&D Systems. AntiRON and an anti-phosphoRON were from Santa Cruz Biotechnology Inc. Anti-TGase-4 Pab and Mab, respectively from Covalab, ABCAM, and Abnova. ROCK small inhibitor (Y27632) was from Santa Cruz Biotechnology Inc. PI-3-K inhibitor, Akt inhibitor, JNK inhibitor II, ERK inhibitor II, Met kinase inhibitor, Wiskostatin, JAK-3 inhibitor, Jak-Stat pathway inhibitor, PLC- $\gamma$ inhibitor and Stat-5 inhibitor were from Calbiochem.

Construction of anti-TGAse-4 hammerhead ribozyme transgenes and TGase-4 expression vector. Hammerhead ribozymes that specifically target a GTC site of the human prostate TGase-4 (GenBank accession NM_003241) were generated as previously described $(13,25)$, using the respective primers (Table I) and the transgene constructed using a pEF6/V5-His vector (Invitrogen, Paisley, Scotland, UK). The following stably transfected cells were established: TGase-4 knock-down cells (CAHPV10 ${ }^{\Delta \mathrm{TGase}} 4$ ), plasmid only control cells (CAHPV10 ${ }^{\mathrm{pEFa}}$ ), and the wild-type, CAHPV10 ${ }^{\mathrm{wt}}$.

Full length human TGase-4 coding region was amplified from a cDNA pool of human prostate tissues using primers listed in Table I. The TGase-4 full length coding product was similarly cloned into the pEF6 vectors. Stably transfected cells were designated as $\mathrm{PC} 3^{\mathrm{pEF} / \mathrm{His}}$ and $\mathrm{PC} 3^{\mathrm{TGase} 4 \mathrm{exp}}$, for control transfection and TGase-4 expression, respectively.

RNA preparation, $R T-P C R$ and quantitative analysis of TGase-4 transcript. The polymerase chain reaction (PCR) was performed using sets of primers, given in Table I. ß-actin was amplified and used as a house-keeping control. The level of the prostate TGase transcripts in the above-prepared cDNA was also determined using a real-time quantitative PCR, based on the Amplifluor ${ }^{\mathrm{TM}}$ technology that was modified from that the previously reported (26). The levels of the transcripts were generated from an internal standard (27) that was simultaneously amplified with the samples.

Electric cell-substrate impedance sensing (ECIS) based cell adhesion assay. Two models of ECIS instrument were used: ECIS9600 for screening and ECIS1600R for modelling. In both systems, 8W10 arrays were used (Applied Biophysics Inc., Troy, NY, USA) $(28,29)$. Following treating the array surface with a Cysteine solution, the arrays were incubated with complete medium for $1 \mathrm{~h}$. The same number of prostate cancer cells, PC3 $3^{\mathrm{pEF} / \mathrm{His}}, \mathrm{PC}^{\mathrm{TGase} 4 \mathrm{exp}}$, or PC3 ${ }^{\mathrm{wt}}, \mathrm{CAHPV}^{\Delta \mathrm{TG} \text { ase } 4}$, CAHPV $^{\mathrm{pEF} / \mathrm{His}}$ or CAHPV ${ }^{\mathrm{wt}}$ (300,000 per well) were added to each wells. Electric changes were continuously monitored for up to $24 \mathrm{~h}$. In the 9600 system, the monitoring was fixed at $30 \mathrm{~Hz}$. In the $1600 \mathrm{R}$ system, two conditions were recorded: 400, 4,000 and 40,000 $\mathrm{Hz}$ for screening the nature of changes and $4,000 \mathrm{~Hz}$ fix frequency for cell modelling (30).

Detection of RON/HGFLR activation using Western blotting. Prostate cancer cells were subject to serum before being treated with either plain medium, rhHGFL/MSP or sodium orthovanadate $\left(10 \mu \mathrm{M}\right.$ in the presence of $1 \% \mathrm{H}_{2} \mathrm{O}_{2}$, as positive control). The proteins were loaded onto $8 \%$ SDS-PAGE. Following blotting, the membranes were first blocked by $10 \%$ semi-skimmed milk before probing with anti-RON or antiphosphoRON (Tyr1238/1239) antibody. After being processed in enhanced chemiluminescent solution, images were obtained using the LumiDoc imaging system (UniDoc, Cambridge, UK).

Immunofluorescence staining of TGase-4 and the HGF-L receptor, RON in cells and tissues. Fresh prostate tissues (normal and tumour) were collected immediately after radical prostectomy. Frozen sections of prostate tissues (normal and tumour) were cut at a thickness of $6 \mu \mathrm{m}$ using a cryostat. Fixed sections were incubated in a blocking solution and probed with the primary antibodies, followed by the secondary FITCand TRITC-conjugated in the presence of Hoechst 33258 at $10 \mu \mathrm{g} / \mathrm{ml}$ (Sigma, St. Louis, MO, USA), separated by extensive washings. The images were documented using Cell Lysis software (Olympus). 
Table I. Primer and oligo-sequences used in the study.

\begin{tabular}{|c|c|c|}
\hline & Sense $\left(5^{\prime}-3^{\prime}\right)$ & Antisense (5'-3') \\
\hline TGase-4 expression & Atgatggatgcatcaaaaga & Ctacttggtgatgagaacaatcttctga \\
\hline TGase-4 ribozyme1 & Atgatggatgcatcaaaagag & Ctacttggtgatgagaacaa \\
\hline TGase-4 ribozyme1 & ctgcagtttggaactcccatgtgtggtgactgatgagtccgtgagga & actagttgaatcaggacaacgccgtttttcgtcctcacgga \\
\hline TGase-4 ribozyme2 & ctgcagttcagttggtggtggtagctgatgagtccgtgagga & actagtccagcccetacaatttcgtcctcacggga \\
\hline TGase-4 (position 62) & atggatgcatcaaaagagc & $\begin{array}{l}\text { Aggtgaaacacctgtcctc Aactgaacctgaccgtacaa } \\
\text { ggtgaaacacctgtcctc, for Q-PCR) }\end{array}$ \\
\hline TGase-4 (position 1957) & ataaaatgcacccaataaa & $\begin{array}{l}\text { Ctacttggtgatgagaacaatc(actgaacctgaccgtacacc } \\
\text { tacttggtgatgagaacaatc, for Q-PCR) }\end{array}$ \\
\hline GAPDH & agcttgtcatcaatggaaat & cttcaccaccttcttgatgt \\
\hline GAPDH for Q-PCR & ctgagtacgtcgtggagtc & Actgaacctgaccgtacacagagatgatgacccttttg \\
\hline$\beta$-actin & atgatatcgccgcgctcg & cgctcgtgtaggatcttca \\
\hline
\end{tabular}

Statistical analysis was carried out using Minitab. For normality test Anderson-Darling test and for statistical difference Student's t-test were used.

\section{Results}

TGase-4 co-localises with RON in CAHPVIO prostate cancer cells, cells highly expressing TGase-4. To test if there is a spatial relationship between TGase- 4 and RON, we selected CAHPV10 cells, a cell type that was shown to highly express TGase-4 in comparison with other prostate cancer cells. Using dual immunofluorescence staining, a clear co-localisation was seen (Fig. 1A, left). It is noteworthy that the co-localised TGase- 4 and RON are seen at the cell periphery (arrows) and cell-cell adhesion areas (arrowheads), with degree of intracellular staining. The superimposed images have shown that the co-localisations occur more prominently at the cell-cell junction area and cell peripheries. Forced expression of TGase-4 in PC-3 cells (PC3 $3^{\text {TGasetexp }}$ ) also resulted in degree of co-localisation of TGase-4 and RON, primarily at the cell periphery (Fig. 1A, arrows) and in the cytoplasm region (arrowheads). CAHPV10 cells showing high level expression of TGase-4, were tranfected with the anti-TGase-4 ribozyme transgene. Cells which had virtually lost the TGase- 4 transcript $\left(\mathrm{CAHPV}^{\Delta \mathrm{TGase} 4}\right)$ as the result of the transgene, were obtained.

Similar to the CAHPV, PC3 ${ }^{\text {TGase4exp }}$ which now expressed good level of TGase-4 following transfection, also showed co-localised TGase- 4 and RON. Co-localisations are seen in both cell-cell contact areas as well as in the cytoplasmic regions (indicated by arrows in the merged image) (Fig. 1A, right panel).

Co-localisation of TGase-4 and RON in human prostate tissues. Using dual immunofluorescence staining of HGFLR/ RON and TGase-4, we attempted to address if the two proteins also co-localised in human prostate tissues. As shown in an example in Fig. 1B, TGase-4 and RON showed a high degree of co-localisation in the tissues at the locations seen with the cells. In addition, TGase-4 proteins were seen in both extracellular matrix and in the cytosol in the tissues.

Forced expression of TGase-4 in PC3 cells increases cell motility, the change is directly affected by RON. Using cells of which TGase-4 expression was genetically manipulated, we first tested the impact on the cell motility using a Electric Cell Impedance Sensing (ECIS) assay. As shown in Fig. 2, loss of TGase-4 in CAHPV10 cells by way of ribozyme (Fig. 2A) and forced expression of TGase-4 in PC-3 cells (Fig. 2B) resulted in increased in cell motility, as demonstrated by rapid rise of resistance $(\mathrm{R})$ after electric wounding.

To test the impact of RON on TGase- 4 mediated cell motility, we used a neutralising antibody to human RON protein on PC-3 cells, which had good level of expression of both RON and its ligand HGF-L. Interestingly, anti-RON blocked the migration of PC-3 control cells after wounding, however, the impact of anti-RON on PC $3^{\text {TGase4exp }}$ cells was very limited (Fig. 2B). Likewise, we have evidence to show that neutralising anti-RON was able to reduce the cell adhesion to the electrode in PC3-control cells and that PC3 $3^{\text {TGase4exp }}$ cells had lost this response.

Impact of rhHGFL and anti-RON/HGFLR on the motility of prostate cancer cells. Using ECIS based cell modelling of cell motility, we showed that recombinant human HGFLfg/MSP significantly increase the motility of control cells (Fig. 2C). However, PC3 ${ }^{\text {TGasetexp }}$ cells, the motility of which was increased, did not shown a significant response to rhHGFL/MSP (Fig. 2C). Neutralising anti-RON antibody resulted in a significant reduction of the motility in control cells, but not in PC $3^{\text {TGase4exp }}$ cells.

RON/HGFLR activation by rhHGFL/MSP and TGase-4 overexpression. Using a phosphor-specific anti-RON antibody, it was shown that rhMSP resulted in the phosphorylation of 

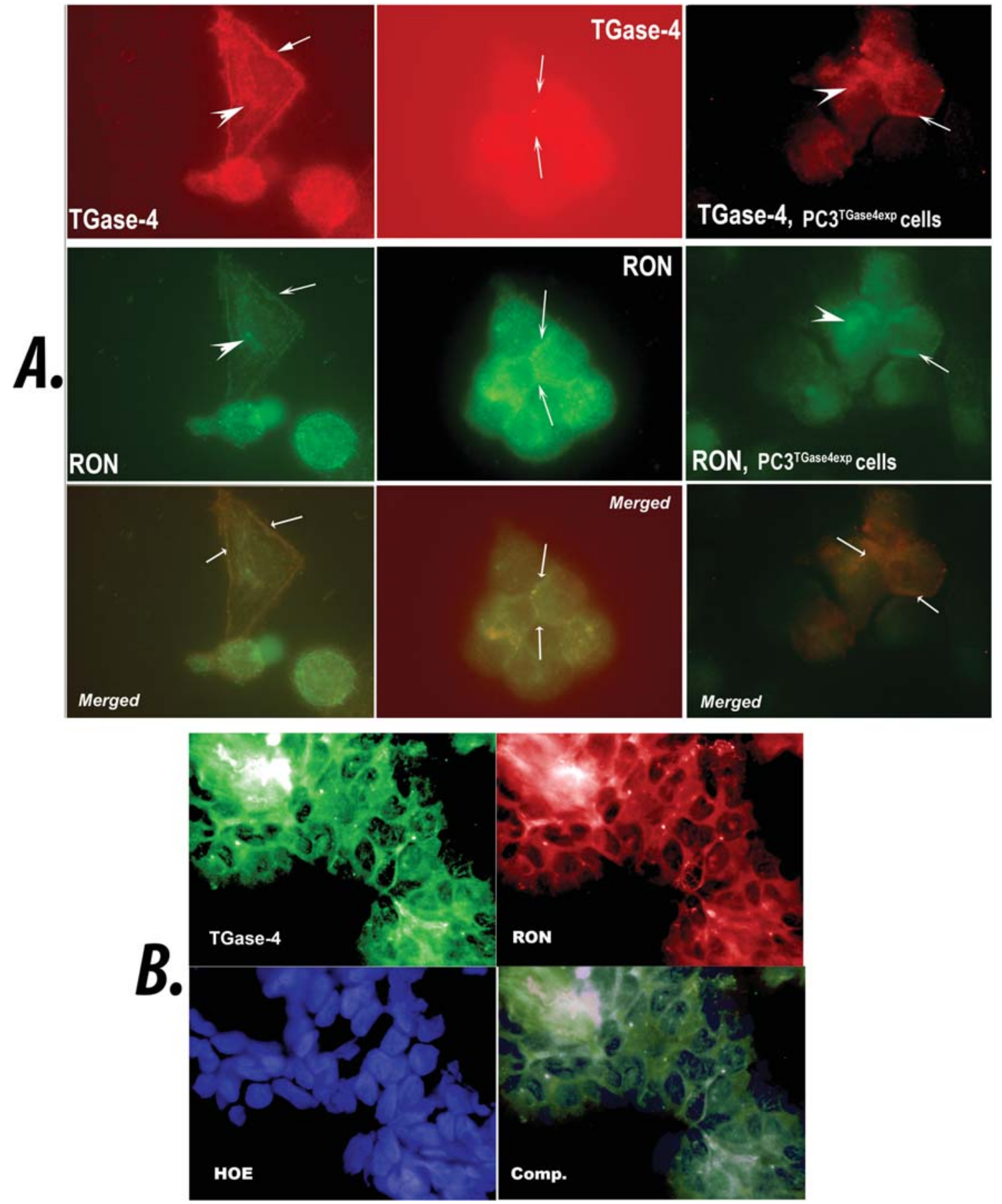

Figure 1. (A) Co-localisation of TGase-4 and RON/HGFLR in CAHPV10 human prostate cancer cell lines (left and middle panels). The two proteins were seen to co-localise at periphery and cell-cell adhesion regions of the cells. Right panel, co-localisation of TGase-4 and RON/HGFLR in PC 3 cells with forced expression of TGase-4 (PC3 ${ }^{\text {TGasetexp }}$ ). Both proteins were seen at the periphery and cell-cell adhesion regions. (B) Co-localisation of TGase-4 and RON/HGFLR in human prostate tissues. HOE, nucleus constained with Hoechst 33258. Comp., superimposed images.

RON at the tyrosine in both wild-type and in control cells. It is interesting to note that autophosphorylation of the receptor was seen in PC3 $3^{\text {TGase4exp }}$ cells, with or without rhHGF-L/MSP (Fig. 3).

Akt inhibitor had a strong inhibitory effect on MSP-induced motility. A panel of small inhibitors to certain key pathways downstream of MSP and RON. Akt inhibitor showed a significant effect on MSP-induced migration both in PC-3 control and PC3 ${ }^{\text {TGase4exp }}$ cells (Fig. 4).

\section{Discussion}

The present study is the first to demonstrate that TGase- 4 , a prostate-specific transglutaminase, acted in orchestration with the HGF-L/MSP receptor RON in enhancing the motility of prostate cancer cells. The study further demonstrated that the TGase-4 induced increase in cell motility is independent of the presence of the RON ligand, HGFL/MSP.

The transglutaminase family has been indicated in the regulation of cell motility and cell-matrix adhesion. Recently, 

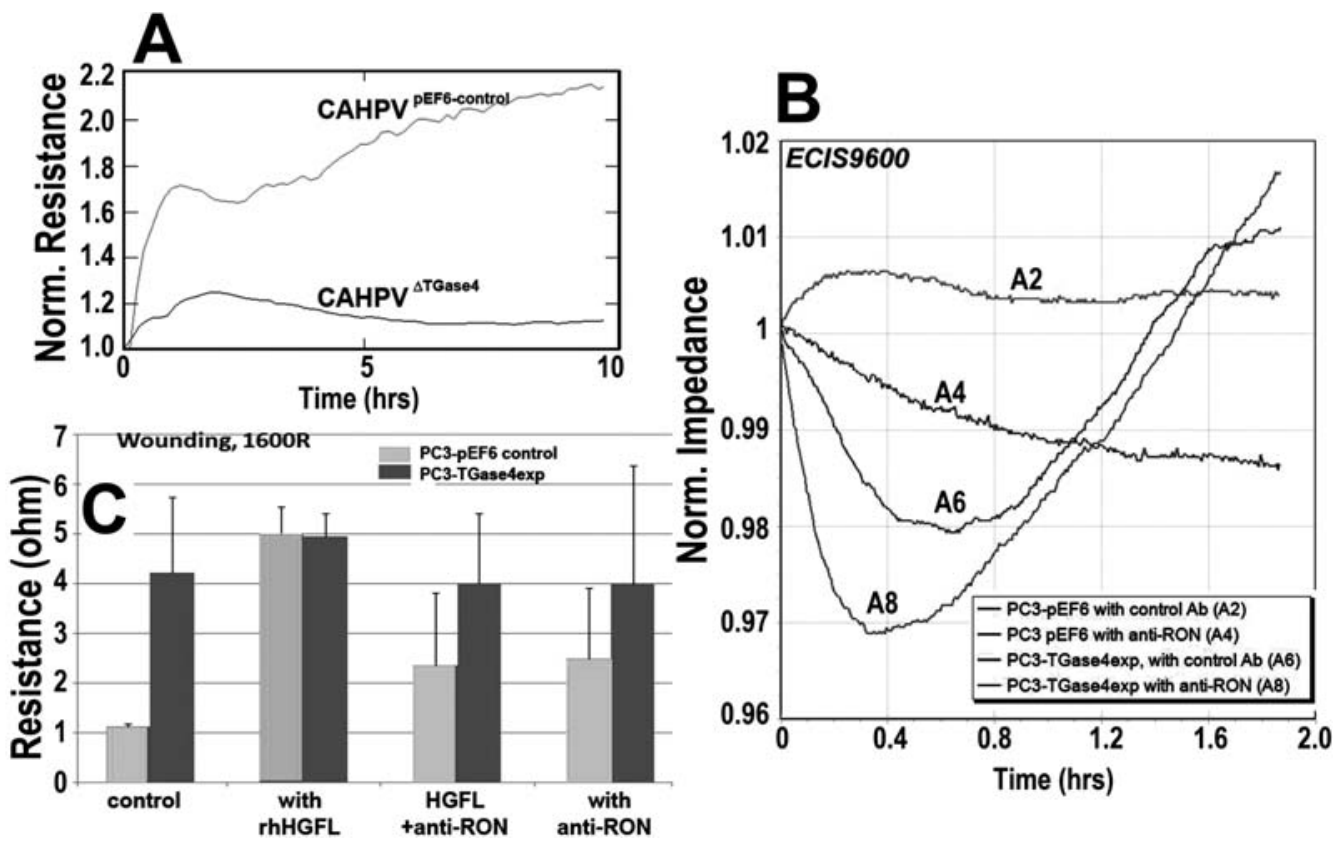

Figure 2. (A) Differential expression of TGase-4 rendered cells with different motility. Knocking down of TGase-4 from CAHPV10 of TGase-4 in PC-3 cells enabled cells to increase migration. (B and C) Effect of rhHGFL/MSP and the neutralising anti-RON antibody on the migration of PC-3 cells. ${ }^{*}$ p $<0.05$ vs control; ${ }^{* *} \mathrm{p}<0.05$ vs with HGF-L only.

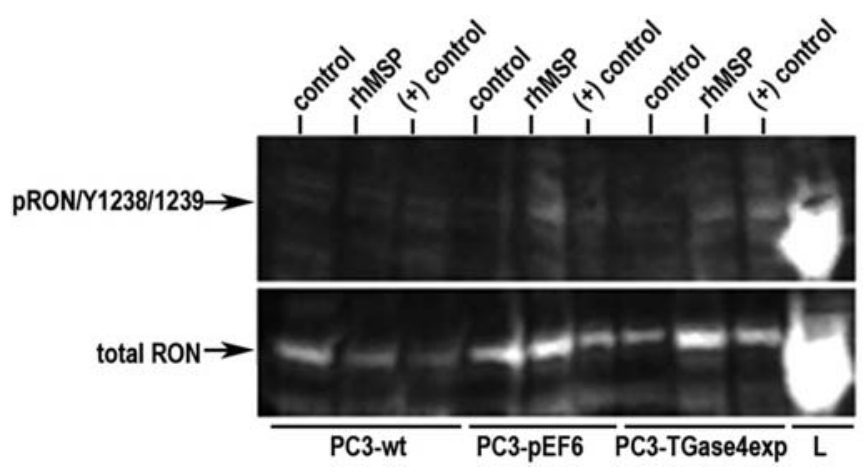

Figure 3. Effect of rhHGFL/MSP and TGase-4 over-expression on the autophosphylation of RON in PC-3 cells. L, total cell lysate.

we have shown that knocking down the expression of TGase4 from a human prostate cancer cell lines, CAHPV which naturally expressed TGase-4, resulted in less motility and adhesive cells (13), an observation leading to suggestion that TGase-4 is also a motility regulator in prostate cancer cells. Motility of cells is regulated by a number of extracellular regulators. It has been well documented that HGF/SF acts via its receptor, cMET, and contributed to the aggressive nature of cancer cells. The present study was the direct result of a proteomic based study in our laboratory in which we found that RON is one of the small number of proteins interacting with TGase-4. In the present study, the spatial co-localisation between TGase- 4 and RON has been confirmed in both prostate cancer cells and in prostate tissues. This is important when considering the potential impact of TGase-4 expression on RON activation and on HGFL/MSP-induced cell motility in prostate cancer cells. First, it is clear that prostate cancer cells over-express TGase-4, i.e., PC3 ${ }^{\text {TGase4exp }}$ autophosphorylates

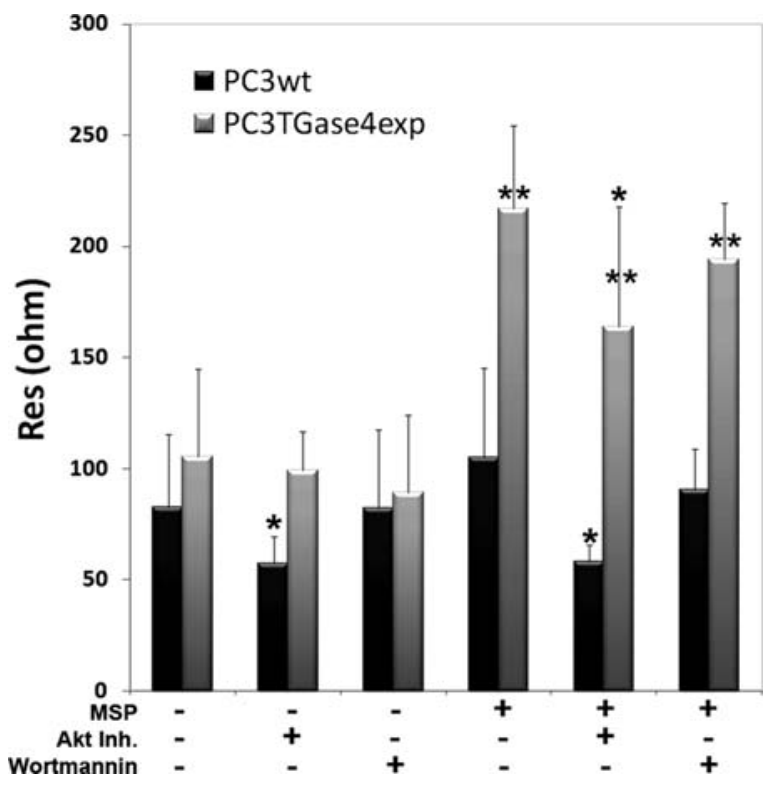

Figure 4. TGase-4 expression and effect of Akt and PI3K pathway inhibitors on the motility of PC-3 cells, determined using the ECIS cell model and analysed by Rb cell modelling. Resistance is shown. MSP used was $40 \mathrm{ng} / \mathrm{ml}$. Akt inhibitor, $200 \mathrm{~nm}$; PI3K inhibitor (wortmannin), $200 \mathrm{~nm}$. " $\mathrm{p}<0.05 \mathrm{vs}$ the respective non-inhibitor control; ${ }^{* *} \mathrm{p}<0.05$ vs the respective $\mathrm{PC} 3^{\mathrm{wt}}$ control.

RON, in the absence of exogenous HGFL/MSP. This indicates that TGase- 4 by either a direct or an indirect mechanism, resulted in the activation of the RON kinase. Second, TGase- 4 expressing cells with RON activation displayed increase in cell motility, independent of HGFL/MSP and that neutralising antibody to RON had no impact on the increased motility of the cells. Collectively, acquisition of TGase- 4 expression in prostate cancer cells 
enabled the cells to have auto-activated RON, which in turn elicits the activation mechanism for cell motility.

HGFL/MSP-induced motility in cells is known to be mediated by a number of key pathways, including Akt and PI3K pathways. The present study has shown that Akt is probably more actively involved in the action as the small inhibitor significantly blocked the action of HGFL/MSP in both PC3 control and PC3 TGase-4exp cells.

The observations reported here have important implications to prostate cancer. Over-expression of HGF-L/MSP and its receptor RON have been reported in a few human solid tumours, including pancreatic cancer, breast cancer, thyroid and lung cancer. No large scale study is presently available with regard to the expression pattern of the cytokine and receptor in prostate cancer. In a recent study with small number of prostate tumours $(n=40), 10 \%$ of the prostate tumours were found to over-express the RON protein. Here, the limited information has shown the presence of RON in prostate cancer cell lines that can be activated by HGF-L/MSP and staining of RON in prostate epithelial cells and cancer cells. Clearly, a large scale study is necessary in order to establish the expression pattern and relationship with tumour development and progression in prostate cancer.

In conclusion, TGase- 4 in prostate cancer cells is colocalised with the HGF-L/MSP receptor RON. When overexpressed, TGase-4 prostate cancer cells showed an enhanced response to HGF-L/MSP as demonstrated by their increased cell motility. This response appears to be Akt-dependent. These observations suggest that: i) TGase-4 and HGFL/MSP may have a synergistic effect toward initiating the aggressive behaviour of prostate cancer cells and ii) targeting both RON and TGase- 4 may be a plausible approach for therapeutic intervention in prostate cancer.

\section{Acknowledgements}

This study was supported by Cancer Research Wales, the Ablin Foundation and the Albert Hung Foundation.

\section{References}

1. Dubbink HJ, Verkaik NS, Faber PW, et al: Romijn: tissuespecific and androgen-regulated expression of human prostatespecific transglutaminase. Biochem J 315: 901-908, 1996.

2. Grant FJ, Taylor DA, Sheppard PO, et al: Molecular cloning and characterization of a novel transglutaminase cDNA from a human prostate cDNA library. Biochem Biophys Res Commun 203: 1117-1123, 1994.

3. Gentile V, Grant FJ, Porta R and Baldini A: Localization of the human prostate transglutaminase (type IV) gene (transglutaminase-4) to chromosome 3p21.33-p22 by fluorescence in situ hybridization. Genomics 27: 219-220, 1995.

4. Ablin RJ and Gonder MJ: Male accessory sexual glands secretions and their antithetical role in immunosurveillance. In: Protides of the Biological Fluids. Peeters H (ed). Pergamon Press Ltd., Oxford, pp271-276, 1985.

5. Ablin RJ, Bartkus JM, Gonder MJ, et al (eds): Factors contributing to suppression of tumor-host responsiveness. In: Human Tumor Markers - Biology and Clinical Applications. Walter de Gruyter, Berlin, pp279-299, 1987.

6. Lee J, Kim YS, Choi DH, et al: Transglutaminase 2 induces nuclear factor-kappaB activation via a novel pathway in BV-2 microglia. J Biol Chem 279: 53725-57235, 2004.

7. Mann AP, Verma A, Sethi G, et al: Overexpression of tissue transglutaminase leads to constitutive activation of nuclear factor-kappaB in cancer cells: delineation of a novel pathway. Cancer Res 66: 8788-8795, 2006.
8. Nunes I, Gleizes PE, Metz CN and Rifkin DB: Latent transforming growth factor-beta binding protein domains involved in activation and transglutaminase-dependent cross-linking of latent transforming growth factor-beta. J Cell Biol 136: 1151-1163, 1997.

9. Belkin AM, Akimov SS, Zaritskaya LS, et al: Matrix-dependent proteolysis of surface transglutaminase by membrane-type metalloproteinase regulates cancer cell adhesion and locomotion. J Biol Chem 276: 18415-18422, 2001.

10. Grigoriev MY, Suspitsin EN, Togo AV, et al: Tissue transglutaminase expression in breast carcinomas. J Exp Clin Cancer Res 20: 265-268, 2001.

11. An G, Meka CS, Bright SP and Veltri RW: Human prostatespecific transglutaminase gene: promoter cloning, tissuespecific expression, and down-regulation in metastatic prostate cancer. Urology 54: 1105-1111, 1999.

12. Dubbink HJ, Hoedemaeker RF, van der Kwast TH, et al: Human prostate-specific transglutaminase: a new prostatic marker with a unique distribution pattern. Lab Invest 79: 141-150, 1999.

13. Davies G, Ablin RJ, Mason MD and Jiang WG: Expression of the prostate transglutaminase (TGase-4) in prostate cancer cells and its impact on the invasiveness of prostate cancer. J Exp Ther Oncol 6: 257-264, 2007.

14. Dubbink HJ, De Waal L, van Haperen R, et al: The human prostate-specific transglutaminase gene (transglutaminase-4): genomic organization, tissue-specific expression, and promoter characterization. Genomics 51: 434-444, 1998

15. Williams-Ashman HG: Transglutaminases and the clotting of mammalian seminal fluids. Mol Cell Biochem 58: 51-61, 1984.

16. Ablin RJ and Whyard TC: Identification and possible biological relevance of spermatozoal transglutaminase. Experientia 47: 277-279, 1991 .

17. Jiang WG, Ablin RJ, Kynaston HG and Mason MD: The prostate transglutaminase (TGase-4, TGaseP) regulates the interaction of prostate cancer and vascular endothelial cells, a potential role for the ROCK pathway. Microvasc Res 77: 150-157, 2009.

18. Ronsin C, Muscatelli F, Mattei MG and Breathnach R: A novel putative receptor protein tyrosine kinase of the met family. Oncogene 8: 1195-1202, 1993.

19. Sakamoto O, Iwama A, Amitani R, et al: Role of macrophagestimulating protein and its receptor, RON tyrosine kinase, in ciliary motility. J Clin Invest 99: 701-709, 1997.

20. Maggiora P, Marchio S, Stella MC, et al: Overexpression of the RON gene in human breast carcinoma. Oncogene 16: 2927-2933, 1998.

21. Welm AL, Sneddon JB, Taylor BC, et al: The macrophagestimulating protein pathway promotes metastasis in a mouse model for breast cancer and predicts poor prognosis in humans. Proc Natl Acad Sci USA 104: 7570-7575, 2007.

22. Peace PE, Hughes MJ, Degen SJ and Waltz SE: Point mutations and overexpression of RON induce transformation, tumor formation, and metastasis. Oncogene 20: 6142-6151, 2001.

23. Willett CG, Wang MH, Emanuel RL, et al: Macrophagestimulating protein and its receptor in non-small-cell lung tumors: induction of receptor tyrosine phosphorylation and cell migration. Am J Respir Cell Mol Biol 18: 489-496, 1998.

24. Camp ER, Yang A, Gray MJ, et al: Tyrosine kinase receptor RON in human pancreatic cancer: expression, function, and validation as a target. Cancer 109: 1030-1039, 2007.

25. Fernando H, Sanders AJ, Kynaston $H$ and Jiang WG: WAVE3 is associated with invasiveness but not cell proliferation in prostate cancer cells. Urol Oncol (In press).

26. Cai J, Parr C, Jiang WG and Boulton ME: Expression of pigment epithelial derived factor (PEDF) in human breast cancer and the impact on angiogenesis. Clin Cancer Res 12: 3510-3517, 2006.

27. Cunnick G, Jiang WG, Gomez KF and Mansel RE: Quantitation of lymphangiogenesis using real time quantitative PCR and breast cancer as a model. Biochem Biophys Res Commun 288: 1143-1146, 2001 .

28. Giaever I and Keese CR: Micromotion of mammalian cells measured electrically. Proc Natl Acad Sci USA 88: 7896-7900, 2001.

29. Keese CR, Wegener J, Walker SR and Giaever I: Electrical wound-healing assay for cells in vitro. Proc Natl Acad Sci USA 101: 1554-1559, 2004.

30. Jiang WG, Martin TA, Russell-Lewis J, et al: Eplin-alpha expression in human breast cancer, the impact on cellular migration and clinical outcome. Mol Cancer 7: 71, 2008. 